\title{
Summary of the Ground-Water-Level Hydrologic Conditions in New Jersey 2006
}

Ground water is one of the Nation's most important natural resources. It provides about 40 percent of our Nation's public water supply. Currently, nearly one-half of New Jersey's drinking-water is supplied by over 300,000 wells that serve more than 4.3 million people (John P. Nawyn, U.S. Geological Survey, written commun., 2007). New Jersey's population is projected to grow by more than a million people by 2030 (U.S. Census Bureau, accessed March 2, 2006, at http://www. census.gov). As demand for water increases, managing the development and use of the ground-water resource so that the supply can be maintained for an indefinite time without causing unacceptable environmental, economic, or social consequences is of paramount importance.

This report describes the U.S. Geological Survey (USGS) New Jersey Water Science Center Observation Well Networks. Record low ground-water levels during water year 2006 (October 1, 2005 to September 30, 2006) are listed, and water levels in six selected water-table observation wells and three selected confined wells are shown in hydrographs. The report describes the trends in water levels in various confined aquifers in southern New Jersey and in water-table and fracture rock aquifers throughout the State. Web site addresses to access the data also are included.

The USGS has operated a network of observation wells in New Jersey since 1923 for the purpose of monitoring groundwater-level changes throughout the State. Long-term systematic measurement of water levels in observation wells provides the data needed to evaluate changes in the ground-water resource over time. Records of ground-water levels are used to evaluate the effects of climate changes and water-supply development, to develop ground-water models, and to forecast trends.

\section{Water-level monitoring in 2006}

During water year 2006, ground-water levels were measured in 217 network wells: 163 wells were equipped for continuous water-level monitoring, and 54 wells were measured manually from two to six times per year. Twenty of the continuously monitored wells are equipped with satellite data-collection platforms that provide near real-time data. The locations of ground-water-level observation wells in New Jersey used during the 2006 water year are shown in figure 1. A map with the locations of wells with hydrographs presented in this report is shown on the inset in figure 1. The published data for water year 2006 including site information, tables of water-levels, and water-level hydrographs are available at http://pubs.water.usgs. gov/wdr2006.

Wells in which water levels exceeded their previous measured extremes (highest or lowest water levels), and for which more than 3 years of data are available, are listed in table 1 . Previous record low water levels were exceeded in 29 of the 217 wells in the statewide observation-well network during the 2006 water year. Twenty-six of the record low water levels were in wells located in the Coastal Plain, and three were in wells in the northern part of the State. Ten of these record low levels are the result of increasing withdrawals from wells that tap two confined aquifers - the Atlantic City 800-foot sand of the Kirkwood Formation and the Piney Point aquifer in the southern part of the State. Previous record high water levels were exceeded in 10 network observation wells during the 2006 water year.

\section{Water-levels in unconfined and fractured rock aquifers}

New Jersey's average annual precipitation ranges from about 40 inches along the southeastern coast to 51 inches in the north-central part of the State. Statewide, the annual mean precipitation is 44.9 inches per water year based on precipitation during 1895-2006 (Office of the N.J. State Climatologist, Rutgers University, New Jersey, unpub. data, accessed Feb. 6, 2006, at http://climate.rutgers.edu). Monthly precipitation and long-term monthly average precipitation for the same period is shown in figure 2. Water levels in wells completed in unconfined and fractured rock aquifers are directly related to the amount of annual precipitation, which was more than 11 inches above average during the 2006 water year.

The effects of climate on daily mean water levels in six drought-network observation wells during water year 2006 can be seen in the hydrographs shown in figure 3. Monthly extreme and long-term average water levels are shown for comparison. The Taylor, Readington School 11, and Cranston Farms 15 observation wells (NJ-WRD well numbers 37-202, 19-270, and 21-364) are open to fractured-rock aquifers. The Morrell 1, Lebanon State Forest 23-D, and Vocational School 2 observation wells (NJ-WRD well numbers 23-104, 05-689, 11-42) tap unconfined sand and gravel aquifers. The wettest fall on record caused ground-water levels to rise at the beginning of the 2006 water year. The highest ground-water levels of the year occurred in many wells during February and the first week of March. Water-level declines resulting from the driest March on record (less than 1 inch of rain) occurred in most wells.

Water levels in most wells that tap unconfined aquifers in the Coastal Plain show the effects of recent climate patterns. Low water levels in 1995, 1998, 1999, 2001, and 2002 were the result of dry years, and the high water levels in 2003, 2004, and the first 6 months of 2005 were the result of the wet years. 


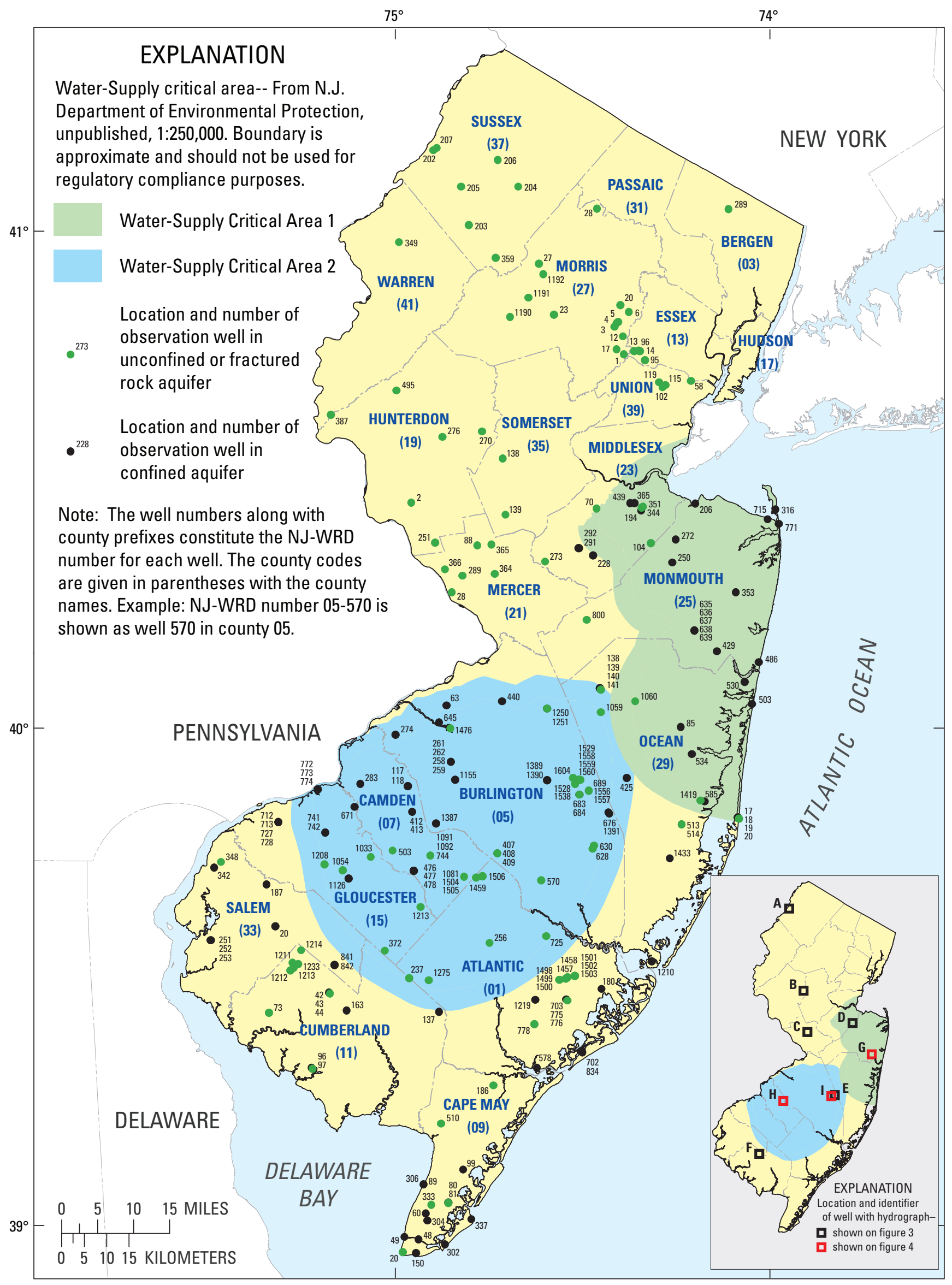

Figure 1. Location of ground-water observation wells in New Jersey and locations of wells with hydrographs in this report. 
Table 1. Water-level records set during the 2006 water year, in observation wells with more than 3 years of data.

\begin{tabular}{|c|c|c|c|c|c|}
\hline \multirow[b]{2}{*}{$\begin{array}{c}\text { NJ WRD } \\
\text { well number }\end{array}$} & \multirow[b]{2}{*}{ Local well name } & \multirow[b]{2}{*}{ Aquifer code } & \multicolumn{3}{|c|}{ Record lows } \\
\hline & & & $\begin{array}{l}\text { Lowest water level, in } \\
\text { feet below land surface }\end{array}$ & $\begin{array}{l}\text { Value by which previous record } \\
\text { low was exceeded, in feet }\end{array}$ & $\begin{array}{c}\text { Year record } \\
\text { began }\end{array}$ \\
\hline 01-180 & Oceanville $1 \mathrm{Obs}$ & 122KRKDL & 80.17 & 1.89 & 1959 \\
\hline $01-578$ & Jobs Point Obs & 122KRKDL & 89.54 & 1.37 & 1959 \\
\hline 01-702 & Burk Ave TW Obs & $122 \mathrm{KRKDL}$ & 128.22 & 3.81 & 1985 \\
\hline $01-703$ & FAA Pomona Obs & 122KRKDL & 106.72 & 2.84 & 1985 \\
\hline $01-834$ & Margate Firehouse $1 \mathrm{Obs}$ & 124PNPN & 42.33 & .65 & 1988 \\
\hline $05-1387$ & Evesham 4 Obs & 211MLRW & 132.72 & 2.71 & 1997 \\
\hline $05-1389$ & New Lisbon 1 Obs & 211MRPAU & 148.14 & 1 & 1997 \\
\hline $05-1391$ & Coyle 2 Obs (OW96) & 211MRPAU & 216.83 & 2.29 & 1997 \\
\hline $05-1476$ & Rancocas St Pk Mw 3 & 211EGLS & 6.83 & .09 & 2003 \\
\hline 09-60 & Airport 7 Obs & $121 \mathrm{CNSY}$ & 44.37 & 1.94 & 1963 \\
\hline $09-80$ & Cape May 42 Obs & $121 \mathrm{CNSY}$ & 24.6 & .63 & 1957 \\
\hline 09-302 & Coast Guard 800 Obs & 122KRKDL & 34 & .52 & 1990 \\
\hline 09-337 & N Wildwood 800 Obs & 122KRKDL & 42.58 & .01 & 1992 \\
\hline $11-44$ & Vocational School 3 Obs & 124PNPN & 140.59 & 8.64 & 1972 \\
\hline $11-96$ & Jones Island 2 Obs & 124PNPN & 63.69 & 7.39 & 1972 \\
\hline $11-163$ & Fair Grounds 3 Obs & $124 \mathrm{PNPN}$ & 115.26 & 8.58 & 1973 \\
\hline $11-1211$ & UDMW01 & 121CKKD & 20.76 & .47 & 2003 \\
\hline $11-1213$ & UDMW02 & 121CKKD & 26.71 & .3 & 2003 \\
\hline $11-1212$ & UDMW03 & 121CKKD & 16.59 & .04 & 2003 \\
\hline $11-1214$ & UDMW04 & 121CKKD & 34.75 & 1.94 & 2003 \\
\hline $11-1233$ & UDMW05 & $121 \mathrm{CKKD}$ & 26.6 & .67 & 2003 \\
\hline 19-2 & Bird Obs & 231SCKN & 17.09 & .05 & 1965 \\
\hline $19-276$ & Environmental Ctr $1 \mathrm{Obs}$ & $231 \mathrm{SCKN}$ & 12.9 & .15 & 1991 \\
\hline $21-365$ & AT\&T North Obs & 227PSSC & 21.03 & 4.15 & 1987 \\
\hline $25-715$ & Atlantic Highlands B Obs & 211EGLS & 226.72 & .25 & 1991 \\
\hline $25-771$ & Sandy Hook 2 Obs & 211EGLS & 10.97 & .01 & 1997 \\
\hline $29-140$ & Colliers Mills 3 Obs & 211MLRW & 29.32 & .1 & 1964 \\
\hline $29-1419$ & MW61 & $121 \mathrm{CKKD}$ & 10.55 & .13 & 2003 \\
\hline \multirow[t]{3}{*}{$33-20$} & Horner Obs & 211MLRW & 54.8 & .46 & 1959 \\
\hline & & & \multicolumn{3}{|c|}{ Record highs } \\
\hline & & & $\begin{array}{l}\text { Highest water level, in } \\
\text { feet below land surface }\end{array}$ & $\begin{array}{l}\text { Value by which previous record } \\
\text { high was exceeded, in feet }\end{array}$ & $\begin{array}{c}\text { Year record } \\
\text { began }\end{array}$ \\
\hline $07-283$ & Egbert Obs & 211MRPAL & 58.1 & .46 & 1963 \\
\hline $13-95$ & Christ Church 2 Obs & 112SFDF & 109.27 & 1.82 & 1991 \\
\hline $13-96$ & East Orange Shallow Obs & 212SFDF & 30.77 & .74 & 1991 \\
\hline $15-671$ & Deptford Deep Obs & 211MRPAL & 72.56 & .01 & 1986 \\
\hline $15-741$ & Mantua Shallow Obs & 211MRPAU & 107.78 & .15 & 1987 \\
\hline $25-429$ & Allaire State Park Obs & 211EGLS & 131.33 & 1.63 & 1964 \\
\hline $25-638$ & Howell Twp 4 Obs & 211EGLS & 103.66 & .08 & 1987 \\
\hline $27-1$ & Recreation Fld Obs & 112 SFDF & 57.7 & 6.14 & 1967 \\
\hline $29-503$ & Mantoloking 6 Obs & 211EGLS & 61.31 & 1.71 & 1983 \\
\hline 29-1419 & MW61 & 121CKKD & 6.36 & .55 & 2003 \\
\hline
\end{tabular}

Aquifer codes:

\begin{tabular}{llll}
\hline 112 SFDF & Stratified drift & 211MLRW & Wenonah-Mount Laurel aquifer \\
121CKKD & Kirkwood-Cohansey aquifer system & 211MRPAU & Upper Potomac-Raritan-Magothy aquifer \\
121CNSY & Cohansey sand & 211 MRPAL & Lower Potomac-Raritan-Magothy aquifer \\
122 KRKDL & Atlantic City 800-foot sand of the Kirkwood Formation & 227PSSC & Brunswick Formation \\
124 PNPN & Piney Point Formation & 231 SCKN & Stockton Formation \\
211EGLS & Englishtown aquifer system & & \\
\hline
\end{tabular}




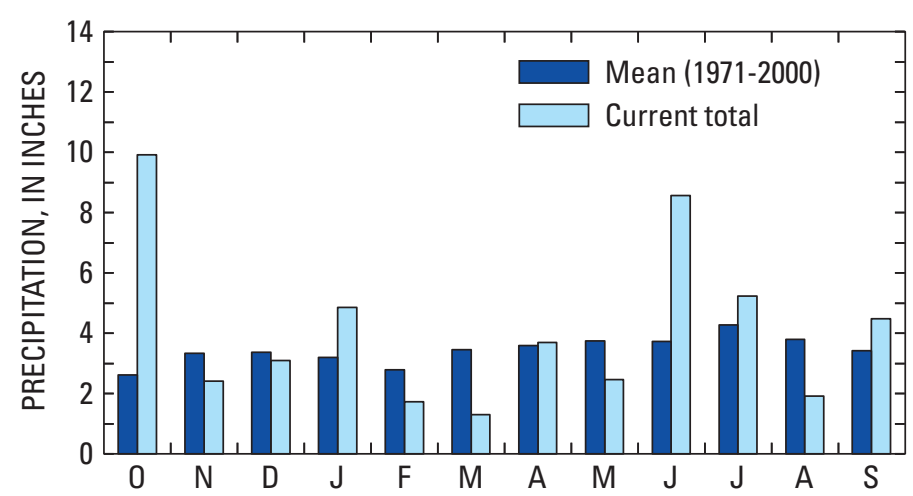

Figure 2. Monthly precipitation at Trenton, New Jersey.

Water levels in many observation wells that tap stratified drift deposits in northern New Jersey rose to their highest level in the last 10 years (27-1, 27-3, 27-4, 27-5, 27-6, 27-12, and 27-17). Most notable was the water level in the Briarwood School well (27-12) where the level rose more than 18 feet from October 2003 to July 2006. This rise was due to a reduction in use of ground water and increased use of surface water in this area in recent years.

\section{Confined aquifers}

Water levels in the confined aquifers in the Coastal Plain of New Jersey have been reacting to changes in withdrawal patterns over the past 10 years. In general, water-level changes in these aquifers are the result of changes in withdrawals rather than climatic variations.

\section{Description of Critical areas}

In 1986, the New Jersey Department of Environmental Protection designated two "Critical Water-Supply Management Areas" in the New Jersey Coastal Plain. (See figure 1.) These designations were initiated as a result of concern about longterm declines in ground-water levels in areas where ground water is the primary source of water supply. Ground-water withdrawals from specified aquifers in these areas were reduced, and new allocations are limited. In Critical Area 1, withdrawals from the Wenonah-Mount Laurel aquifer, the Englishtown aquifer system, and the Upper and Middle Potomac-Raritan-Magothy aquifers are restricted. In Critical Area 2, only withdrawals from the Potomac-Raritan-Magothy aquifer system have been restricted.

In Critical Area 1, water levels rose dramatically from 1991 to 1998 in the Potomac-Raritan-Magothy aquifer system, the Englishtown aquifer system, and the Wenonah-Mount Laurel aquifer. This rise in water levels was the result of the reduction in ground-water withdrawals from this aquifer system. In Critical Area 2, the shift in withdrawals away from the deeper, confined aquifers to surface water and ground water in shallower, confined and unconfined aquifers began in 1996. As a result, beginning in 1996 water levels rose in many observation wells screened in the Potomac-Raritan-Magothy aquifer system in Critical Area 2.
Water levels measured in confined aquifers in the Coastal Plain in water year 2006, together with those measured during previous years, show the effects of the Critical Area cutbacks and changes in ground-water withdrawal patterns. Examples of the water-level recoveries resulting from the critical area cutbacks are shown in figure 4 .

\section{Water-levels in confined wells}

Water levels in the confined Cohansey aquifer in Cape May County have been relatively constant in wells in the northern part of the County. In wells in the southern part of the County (09-48, 09-49, and 09-150), water levels have recovered about 5 feet since 1999 as a result of a reduction in withdrawals related to the use of a desalinization plant in Cape May City, which has provided water for public supply since 1998. Two wells (09-60 and 09-80) set record low levels in August 2006.

Water levels in the Atlantic City 800-foot sand have been affected by withdrawals for the desalination plant. Water levels in the Coast Guard 800 observation well (09-302) have declined more than 15 feet since 1998, and water levels in two wells located north of the desalinization plant (09-306 and 09-337) have declined 8 to 14 feet since 1998. In Atlantic County, water levels have been relatively stable over the past 5 years; however, four observation wells exceeded their previous low of record in August 2006 (01-180, 01-578, 01-702, and 01-703).

Water levels in the Piney Point aquifer throughout much of the southern part of the State continue to decline. Water levels in Piney Point wells in Atlantic County and southern Ocean County continued a long-term decline (01-834, 01-1219, and 29-1210). Water levels in three wells in Cumberland County declined sharply between December 2003 and September 2006 and continue to decline (11-44, 11-96, and 11-163). Water levels in these wells dropped from 19 to 53 feet over this period. Water levels in the aquifer in parts of Ocean and Burlington Counties have been relatively stable (05-407, 05-676, and 29-425). Water levels in the Vincentown aquifer have remained stable over the past 10 years except for periods of drought when levels dropped 1 to 3 feet (05-1250, 25-636, and 29-139).

Water levels in the Wenonah-Mount Laurel aquifer in parts of Burlington, Camden, Gloucester, and Salem Counties had been declining over the last several years but leveled off during 2002-06 (05-1155, 05-1387, and 07-478). The greatest long-term water-level decline in a confined aquifer observation well occurred in the New Brooklyn Park 3 observation well (07-478), which is screened in the Wenonah-Mount Laurel aquifer in Camden County. The water level in this well declined more than 86 feet from December 1962 to December 2001 but has recently leveled off. Water levels in the northern part of the aquifer in Monmouth County and Northern Ocean County leveled off in the past 10 years after recovering as a result of Critical Area 1 withdrawal cutbacks.

Water levels in observation wells that tap the northern part of the Englishtown aquifer system recovered and seem to have leveled off during recent years as a result of Critical Area 1 withdrawal cutbacks (25-715, 29-138, and 29-530); however, water-levels in three wells in northern Ocean County continued to rise to record high levels during the 2006 water year (25-429, 25-638, and 29-503). The water level in the Toms River 2 Obs 
A

Taylor Obs

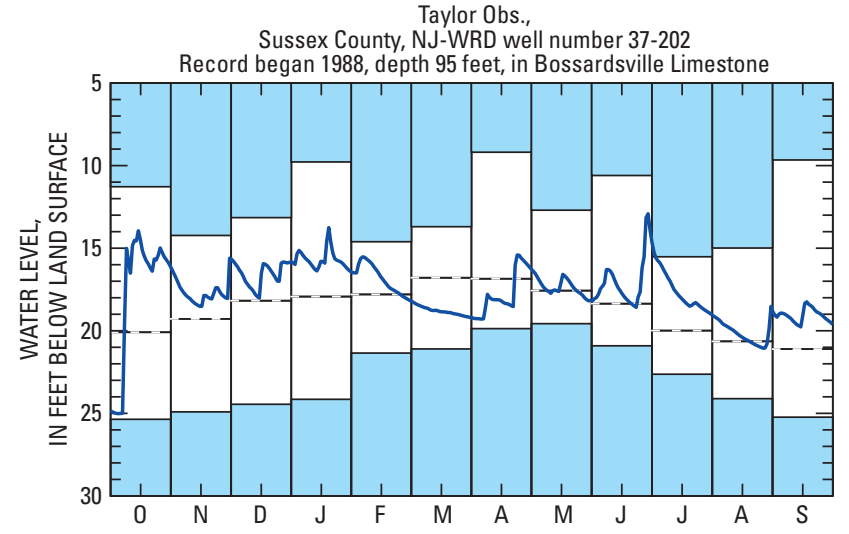

B

Readington School 11 obs.

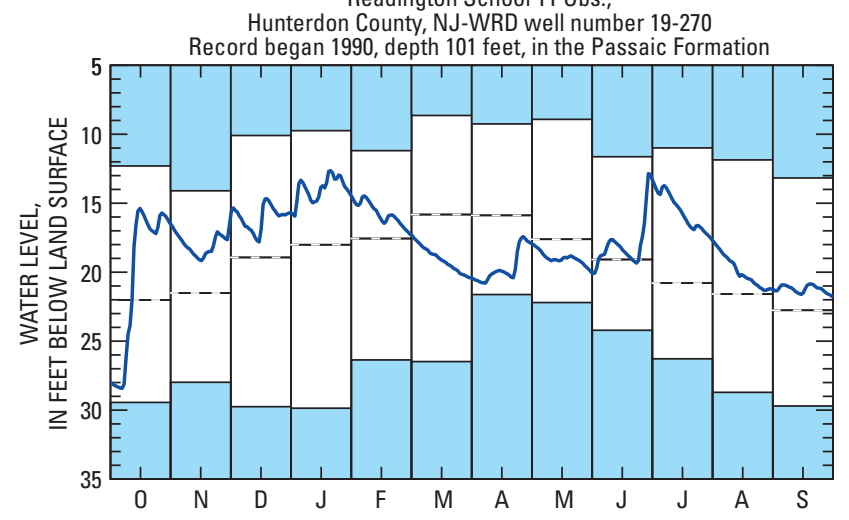

C

Cranston Farms 15 Obs

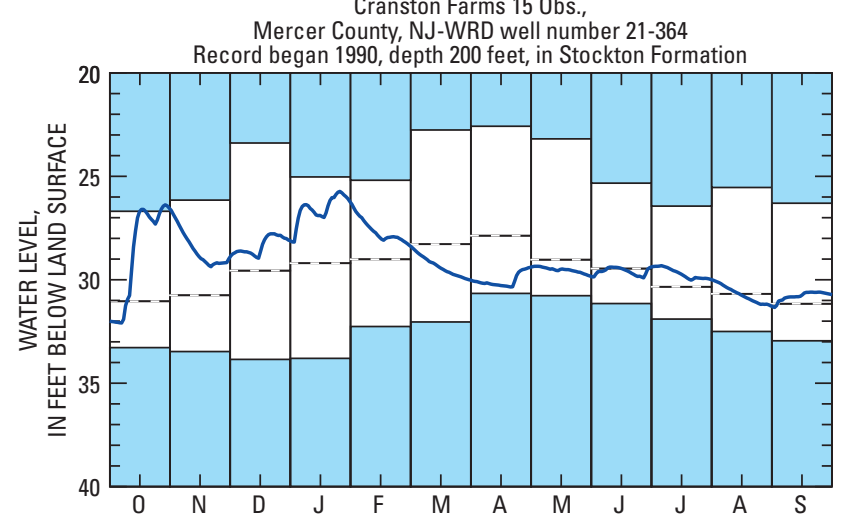

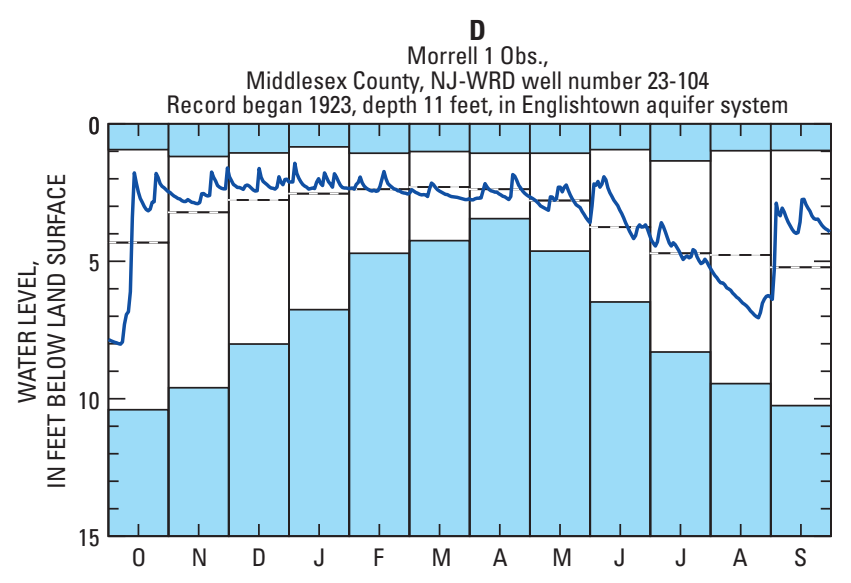

E

Lebanon State Forest 23-D Obs. Burlington County NJ-WRD well number 5-689

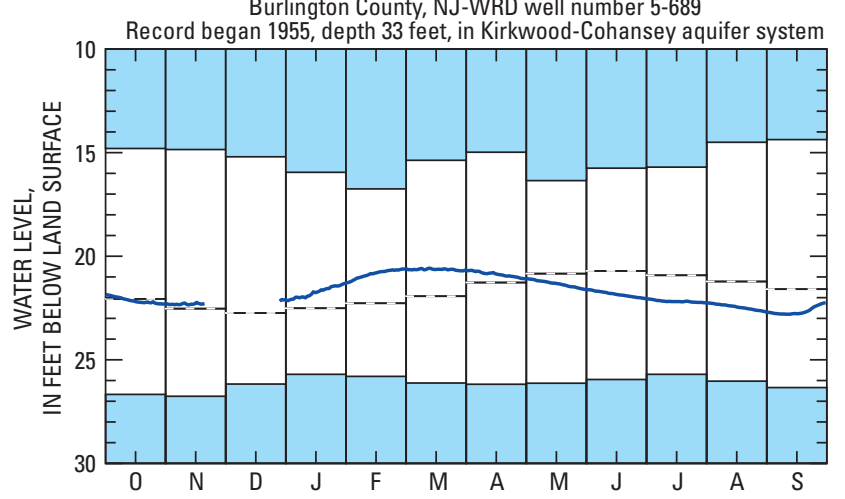

$\mathbf{F}$

Vocational School 2 Obs., Cumberland County, NJ-WRD well number 11-42

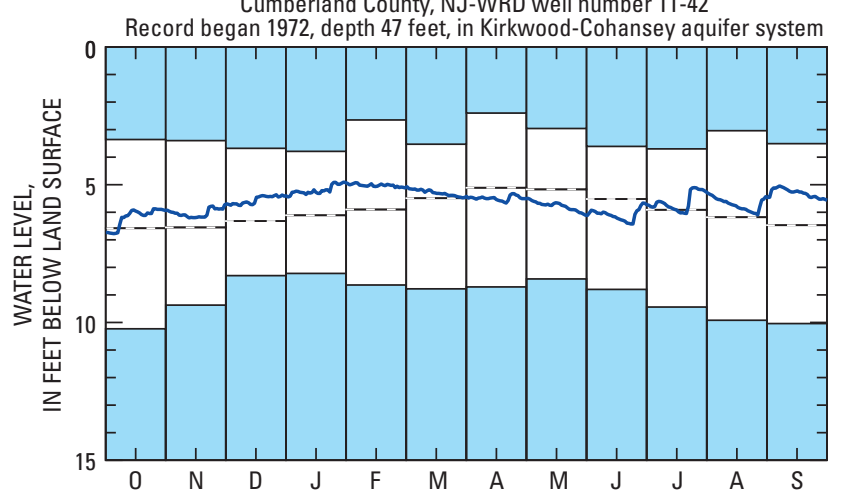

\section{EXPLANATION}

UNSHADED AREA--Indicates range between highest and lowest recorded monthly water level, prior to the current year

DASHED LINE--Indicates mean of monthly mean water levels, prior to the current year

SOLID LINE--Indicates daily mean water levels for the current year; break in line indicates missing data

Figure 3. Ground-water levels in six drought-network observation wells in New Jersey, 2006. 


\section{G}

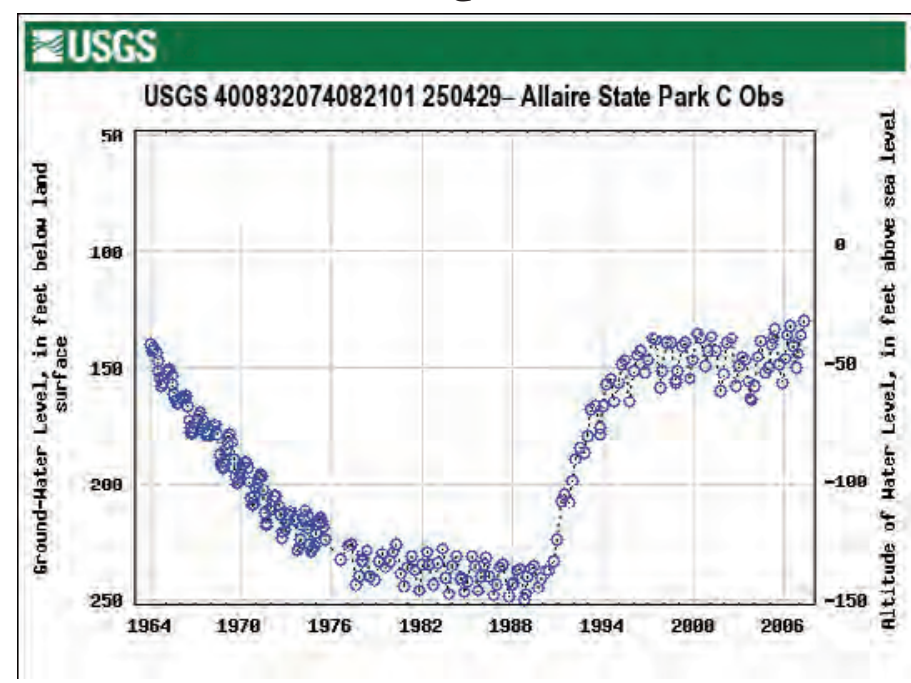

H

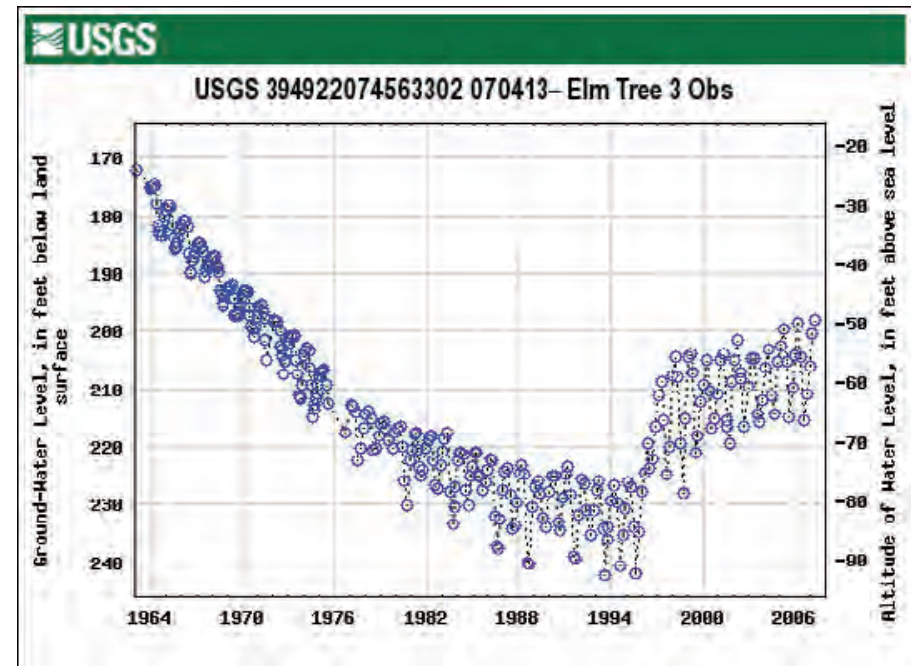

I

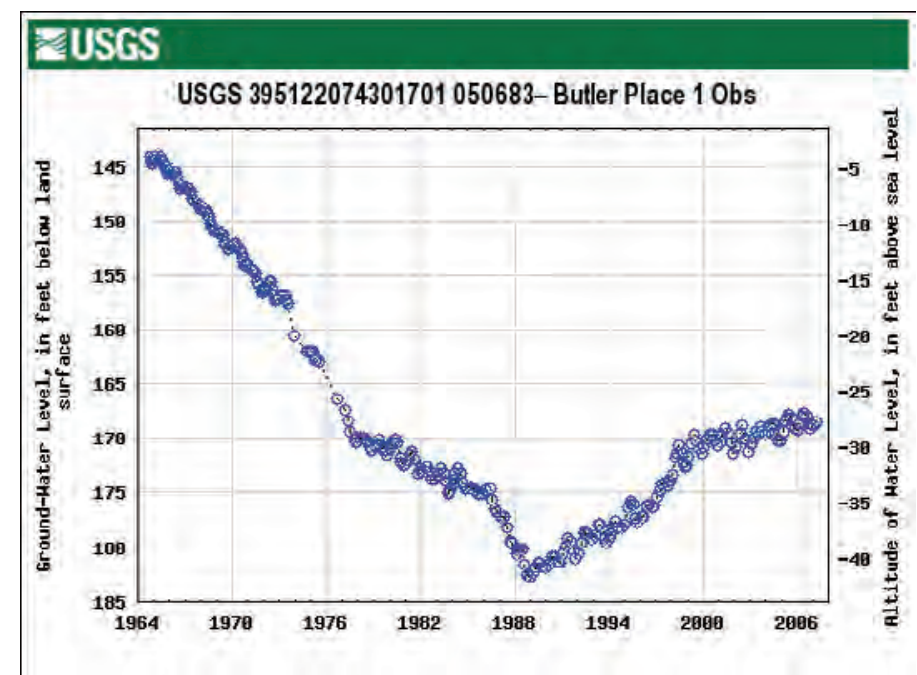

Figure 4. Long-term ground-water levels in wells in Critical WaterSupply Management Areas, New Jersey, 1964-2007. well (29-534) in central Ocean County has risen by more than $27 \mathrm{ft}$ over the past 10 years.

Water levels in the Potomac-Raritan-Magothy aquifer system have been affected by cutbacks in withdrawals in both Critical Areas. Water levels recovered through the late 1990's in the northern part of the aquifer system as a result of the decreased withdrawals in Critical Area 1 but have declined slightly in recent years at several wells in southern Monmouth and northern Ocean Counties (25-635, 25-639, and 29-85). In the vicinity of Critical Area 2 (Burlington, Camden, and Gloucester Counties), water levels began rising in 1996. The recovery continues in most of the wells completed in the Potomac-Raritan-Magothy aquifer system in Burlington, Camden, Gloucester, and parts of Salem Counties.

\section{Availability of data}

The water-level data in the 2006 New Jersey Annual Data Report can be accessed online at http://pubs.water.usgs.gov/ $w d r 2006$. Multiple-year graphs of mean daily water levels and tables of water levels measured in water year 2006 are available at this site. A map interface of the well sites also is available.

A list of the sites in the New Jersey water-level monitoring network and links to historical water-level data at the USGS NWISWEB site are available at http://nj.usgs.gov/gw/ gw_hydrographs.html. Real-time data from a National Ground Water Climate Response Network, which includes the 20 wells equipped with real-time capability in New Jersey, can be accessed at http://groundwaterwatch.usgs.gov/.

by Walter Jones and Daryll Pope

\section{For more information, contact:}

Director, New Jersey Water Science Center

U.S. Geological Survey

810 Bear Tavern Road, Suite 206

West Trenton, NJ 08628

Email: dc_nj@usgs.gov

On the web: http://nj.usgs.gov/ 